\title{
MAKNA PEMILIHAN PRESIDEN BAGI SETIAP ORANG DAN RELEVANSINYA DENGAN PERSPEKTIF ALKITAB
}

\section{Ratna Katharina}

\begin{abstract}
ABSTRAK
Pemilihan umum (pemilu) merupakan merupakan sarana perwujudan kedaulatan rakyat guna menghasilkan pemerintahan negara yang demokratis berdasarkan Pancasila dan UUD 1945. Indonesia mempunyai dua sistem pemilu yaitu Pemilihan Legislatif dan Pemilu Presiden. Pemilihan Presiden bertujuan memilih Presiden dan Wakil Presiden dan dilaksanakan sesudah pemilu legislatif untuk memastikan pemenuhan persyaratan dalam mencalonkan diri menjadi Presiden. Pasangan Presiden dan Wakil Presiden dipilih secara langsung oleh rakyat. Makna pemilu menjadi penting bagi setiap orang yang sudah berhak memilih. Tiga studi kasus pemilihan kepala negara dalam tulisan ini menunjukkan pentingnya pemilu bagi suatu negara. Suara pemilih dapat menentukan terjadinya perubahan ke arah yang lebih baik atau mungkin bahkan sebaliknya. Pemilih mempunyai alasan mau datang ke tempat pemungutan suara (TPS) jika pemilihan umum mempunyai arti baginya. Dalam perspektif Alkitab, agama dan politik merupakan satu kesatuan yang tidak terpisahkan. Agama merupakan unsur faktor moral dalam berpolitik. Seluruh aspek tatanan kehidupan manusia di dunia merupakan kesatuan dari agama dan politik. Alkitab adalah pernyataan visi dan misi Allah bagi dunia melalui sejarah kehidupan manusia sesuai zamannya masing-masing. Implikasinya, menyukseskan pemilu merupakan tanggungjawab orang Kristen.
\end{abstract}

\section{PENDAHULUAN}

Alkitab merupakan firman Allah yang menyatakan visi dan misi Allah bagi dunia. Alkitab menunjukkan bagaimana sejarah kehidupan manusia juga dipakai Allah dalam rangka mewujudkan rencanya bagi dunai tersebut. Bahkan, Alkitab juga memperlihatkan bagaimana Allah menolong umatNya untuk memilih pemimpin yang sesuai dengan rencana Allah sendiri. Para nabi seperti Musa, Yesaya dan Yehezkiel, para hakim seperti otniel, Debora dan Gideon, para raja sepeti Saul dan Daud, para rasul seperti Petrus dan Paulus dan juga sampai para Penatua dan Diaken dalam Titus 1 
merupakan contoh para pemimpin yang mewakili sejarah kehidupan umat Allah di zamannya masing-masing.

Dalam tatanan pemerintah di dunia modern sekarang, pemilu merupakan sarana perwujudan kedaulatan rakyat guna menghasilkan pemerintahan negara yang demokratis. Indonesia mempunyai dua sistem pemilu yaitu Pemilihan Legislatif dan Pemilu Presiden. Pemilu legislatif bertujuan memilih anggota Dewan Perwakilan Rakyat (DPR), Dewan Perwakilan Daerah (DPD), Dewan Perwakilan Rakyat Daerah (DPRD), dan diselenggarakan sebelum pemilihan presiden. Pemilihan Presiden bertujuan memilih Presiden dan Wakil Presiden dan dilaksanakan sesudah pemilu legislatif untuk memastikan pemenuhan persyaratan dalam mencalonkan diri menjadi Presiden. Pasangan Presiden dan Wakil Presiden dipilih secara langsung oleh rakyat.

Tahun 2014 Pemerintah Indonesia kembali menyelenggarakan pemilihan umum. Agar pemilu berjalan dengan baik dan sukses maka pemilu disosialisasikan kepada masyarakat melalui berbagai cara, terutama berbagai media tentunya, agar pemilih mau datang ke tempat pengumutan suara. Suara yang diberikan oleh pemilih yang sudah berhak memilih menentukan terpilihnya pemimpin baru yang tentunya diharapkan membawa perubahan ke arah yang lebih baik. Ada alasan atau dasar apa yang membuat pemilih mau datang ke tempat pemungutan suara (TPS). Tulisan ini akan mengulas makna pemilihan umum bagi setiap orang dan relevansinya dengan perspektif Alkitab.

\section{Sekilas tentang Pemilihan Umum Indonesia ${ }^{1}$}

Sejak digantinya Pemerintahan Soeharto pada tahun 1998, Indonesia telah melaksanakan pemilihan umum sebanyak empat kali yaitu 1999, 2004, 2009, dan 2014. Pemilu di Indonesia terdiri dari Pemilihan Presiden dan Pemilihan Legislatif. Pemilu legislatif adalah pemilu untuk memilih para anggota Dewan Perwakilan Rakyat (DPR) tingkat nasional dan anggota DPR tingkat daerah untuk 33 provinsi dan 497 kabupaten/kota. Untuk tahun 2014 Pemilihan Legilatif sudah dilaksanakan pada tanggal 9 April 2014 dengan hasil 10 partai yang lolos dari urutan perolehan suara terbesar sampai terkecil yaitu Partai Demokrasi Indonesia Perjuangan (PDIP), Partai Golongan Karya (Golkar), Partai Gerakan Indonesia Raya

\footnotetext{
${ }^{1}$ KPU Indonesia, 2014.
} 
(Gerindra), Partai Demokrat (PD), Partai Kebangkitan Bangsa (PKB), Partai Persatuan Pembangunan (PPP), Partai Kesejahteraan Sosial (PKS), Partai Nasional Demokrat (Nasdem), dan Partai Hati Nurani Rakyat (Hanura).

Pemilu presiden dijadwalkan dilaksanakan pada tanggal 9 Juli 2014, dan akan diadakan satu putaran saja karena hanya ada dua pasangan kandidat yang mendaftar ke KPU. Presiden adalah pemimpin kekuasaan eksekutif dan dapat dipilih sebanyak-banyaknya dua kali untuk jangka waktu masing-masing lima (5) tahun. Sebuah partai politik atau koalisi partai politik yang memenangkan 25 persen suara sah atau memperoleh paling sedikit 20 persen kursi DPR dapat mengajukan calon untuk pasangan Presiden dan Wakil Presiden. Pemilihan umum Presiden diadakan setelah Pemilu legislatif guna memastikan pemenuhan persyaratan di atas dalam mencalonkan diri menjadi Presiden. Pasangan Presiden dan Wakil Presiden dipilih secara langsung oleh rakyat. Presiden Indonesia saat ini, Susilo Bambang Yudhoyono, terpilih untuk kedua dan terakhir kalinya pada putaran pertama dalam pemilihan umum tahun 2009 dengan perolehan 60,8 persen dari jumlah suara ${ }^{2}$.

\section{Kerangka Hukum}

Indonesia merupakan sebuah negara Republik di mana Presiden merupakan kepala negara sekaligus kepala pemerintahan. Konstitusi Indonesia Tahun 1945, Undang-Undang Dasar Negara Republik Indonesia Tahun 1945 (UUD 1945), merupakan landasan untuk sistem pemerintahan negara dan yang memisahkan secara terbatas kekuasaan legislatif, eksekutif dan yudikatif.

Kerangka hukum legislatif menyangkut beberapa undang-undang:

- Undang-Undang 15/2011 tentang Penyelenggara Pemilihan Umum

- Undang-Undang 8/2012 tentang Pemilihan Umum Anggota Dewan Perwakilan Rakyat, Dewan Perwakilan Daerah dan Dewan Perwakilan Rakyat Daerah

2 Ibid. 
- Undang-Undang 42/2008 tentang Pemilihan Umum Presiden dan Wakil Presiden

- Undang-Undang 32/2004 tentang Pemerintahan Daerah (mencakup pemilu kepala daerah)

- Undang-Undang 2/2011 tentang Partai Politik

- Undang-Undang 27/2009 tentang Majelis Permusyarawatan Rakyat, Dewan Perwakilan Rakyat, Dewan Perwakilan Daerah, dan Dewan Perwakilan Rakyat Daerah

\section{Partai Politik dan Kandidat}

Indonesia menggunakan sistem multi-partai. Menurut catatan Kementerian Hukum dan Hak Azasi Manusia untuk Pemilu 2014, ada sebanyak 46 partai politik mendaftarkan diri, namun hanya 12 partai politik nasional dan tiga partai politik lokal (hanya boleh bersaing melawan parpol nasional di Aceh) yang sukses melewati proses pendaftaran dan mendapatkan tempat di surat suara. Berikut adalah dua belas partai tersebut berdasarkan nomor urut bersama informasi mengenai jumlah suara yang diperoleh pada Pemilu 2009.

1. NasDem - Partai Nasional Demokrat (partai politik baru)

2. PKB - Partai Kebangkitan nasional (memperoleh 4,95 persen suara/27 kursi di DPR)

3. PKS - Partai Keadilan Sejahtera (memperoleh 7,89 persen suara/57 kursi di DPR)

4. PDI-P - Partai Demokrasi Indonesia Perjuangan (memperoleh 14,01 persen suara/95 kursi di DPR)

5. Golkar - Partai Golongan Karya (memperoleh 14,45 persen suara/107 kursi di DPR)

6. Gerindra - Partai Gerakan Indonesia Raya (memperoleh 4,46 persen suara/26 kursi di DPR) 
7. PD - Partai Demokrat (memperoleh 20,81 persen suara/150 kursi di DPR, merupakan partai dari presiden Republik Indonesia saat ini)

8. PAN - Partai Amanat Nasional (memperoleh 6,03 persen suara/43 kursi di DPR)

9. PPP - Partai Persatuan Pembangunan (memperoleh 5,33 persen suara/33 kursi di DPR)

10. Hanura - Partai Hati Nurani Rakyat (memperoleh 3,77 persen suara/18 kursi di DPR)

11.PDA - Partai Damai Aceh (partai politik baru, hanya bersaing di Aceh)

12. PNA - Partai Nasional Aceh (partai politik baru, hanya bersaing di Aceh)

13. PA - Partai Aceh (hanya bersaing di Aceh; memperoleh 43,9 persen suara/33 kursi di DPRD Provinsi Aceh)

14. PBB - Partai Bulan Bintang (tidak berhasil memperoleh kursi di $\mathrm{DPR})$

15. PKPI - Partai Keadilan dan Persatuan Indonesia (tidak berhasil memperoleh kursi di DPR)

\section{Penyelenggara Pemilihan Umum}

Komisi Pemilihan Umum Republik Indonesia (KPU) adalah lembaga konstitutional independen yang bertanggung jawab untuk menyelenggarakan pemilihan umum nasional dan lokal sebagaimana diamanatkan oleh Undang-Undang No. 15/2011. KPU saat ini terdiri dari 7 anggota (enam laki-laki; satu perempuan) yang dipilih melalui proses seleksi yang ketat dan kemudian dilantik oleh Presiden pada 12 April 2012 untuk jangka waktu lima tahun. Sekretariat KPU, dipimpin oleh Sekretaris Jenderal, merupakan perpanjangan tangan eksekutif dari KPU yang bertanggung jawab untuk administrasi organisasi di tingkat nasional. Sekretaris Jenderal biasanya dicalonkan oleh KPU dan kemudian ditunjuk 
untuk jangka waktu lima tahun oleh Presiden. Sejak tahun 2007, KPU telah mampu merekrut pegawai negeri sipil sebagai staf mereka. Sebelum tahun 2007, sebagian besar stafnya merupakan staf pindahan dari Kementerian Dalam Negeri. Struktur KPU dan Sekretariat provinsi mengikuti struktur di tingkat nasional: seluruh provinsi hanya memiliki lima orang anggota kecuali Aceh, yang memiliki tujuh orang anggota. Saat ini KPU memiliki 13.865 staf di 531 kantor di seluruh Indonesia.

Badan Pengawas Pemilu (Bawaslu) merupakan lembaga yang bertanggung jawab mengawasi agar gugatan terkait pemilu ditujukan kepada badan yang tepat dan diselesaikan secara benar; secara umum, pelanggaran bersifat kriminal dirujuk kepada polisi dan pengadilan biasa, dan pelanggaran administrasi kepada KPU. UU 8/2012 tentang Pemilihan Umum Legislatif memberikan Bawaslu wewenang pemutusan perkara dalam sengketa antara KPU dan peserta Pemilu. Putusan Bawaslu bersifat final terkecuali untuk hal-hal terkait pendaftaran partai politik dan calon legislatif peserta pemilu. Pelanggaran serius yang mempengaruhi hasil pemilu diajukan secara langsung kepada Mahkamah Konstitusi. Ketentuan dalam UU 15/2011 mengatur bahwa Bawaslu dan KPU adalah lembaga yang setara dan terpisah. Anggota Bawaslu dipilih oleh komite seleksi yang sama dengan komite yang memilih anggota KPU. Terdapat lima anggota tetap Bawaslu di tingkat nasional. Rekan sejawat Bawaslu di tingkat provinsi, Bawaslu Provinsi, adalah lembaga yang sekarang sudah bersifat permanen dan beranggotakan tiga orang. Turun dari tingkat provinsi, keanggotaannya bersifat sementara dan terdiri atas tiga anggota di tingkat provinsi, tiga di tingkat kabupaten/kota, tiga di tingkat kecamatan dan satu pengawas lapangan di setiap kelurahan/desa. Badan pengawas semacam ini adalah khas Indonesia.

UU 15/2011 juga menetapkan Dewan Kehormatan Penyelenggara Pemilu (DKPP). DKPP adalah dewan etika tingkat nasional yang ditetapkan untuk memeriksa dan memutuskan gugatan dan/atau laporan terkait tuduhan pelanggaran kode etik yang dilakukan oleh anggota KPU atau Bawaslu. DKPP ditetapkan dua bulan setelah sumpah jabatan anggota KPU dan Bawaslu untuk masa jabatan selama lima tahun, dan terdiri atas seorang perwakilan KPU, seorang perwakilan Bawaslu, dan lima pemimpin masyarakat. DKPP, sebuah jenis lembaga penyelenggara pemilu yang hanya ada di Indonesia, bertugas untuk memastikan bahwa kerja anggota KPU dan Bawaslu memenuhi kode etik bersama dan memiliki kewenangan untuk 
merekomendasikan pemberhentian seorang anggota komisi/badan pengawas. Keputusan DKPP bersifat final dan mengikat.

Dalam hal penyelenggaraan, pemilu di Indonesia adalah pemilu-satuhari. Dalam hal jumlah pemilih, pemilu di Indonesia merupakan jumlah kedua terbesar di dunia - nomor satu Amerika Serikat. Menurut sensus nasional April 2010, total populasi Indonesia saat ini adalah 237,56 juta jiwa. Batas umur minimal sebagai pemilih adalah 17 tahun (pada hari pemilihan) atau usia berapapun asalkan telah/pernah menikah. Daftar Pemilih Sementara (DPS) 2014 yang telah disusun berisi 187.977.268 pemilih. Jumlah pasti pemilih yang terdaftar akan ditentukan saat Daftar Pemilih Tetap (DPT) ditetapkan di tingkat nasional pada tanggal 23 Oktober 2013. Dalam Pemilu 2009, terdapat 171 juta pemilih terdaftar namun hanya 122 juta pemilih yang menggunakan hak pilihnya menunjukkan tingkat partisipasi pemilih sebesar 71 persen - sebuah penurunan drastis dari tingkat partisipasi 93 persen pada Pemilu 1999 dan 84 persen pada Pemilu 2004. Kendati demikian, penurunan tingkat partisipasi bukanlah hal yang aneh bagi sebuah demokrasi yang baru berdiri.

\section{Makna Pemilu Bagi Orang}

Untuk mengerti dan mendapatkan apa makna pemilu bagi setiap orang, dalam tulisan ini, dianalisis tiga peristiwa pemilihan pilpres di tiga negara yaitu Amerika,Taiwan dan Indonesia.

\section{Pilpres Amerika 2004}

Menurut laporan Biro Statistik Tenaga Kerja Amerika, sampai pada bulan Maret tahun 2004 sudah ada 84 juta orang Amerika yang menganggur. Tingkat penganggurannya sebesar 5,7\% di mana 10,2 \% dari tingkat pengangguran tersebut merupakan orang keturunan AfrikaAmerika, Tingkat pengangguran tersebut tidak berubah dibandingkan dengan tahun 20033. Keturunan Afrika-Amerika merupakan etnik grup yang paling tinggi angka penggagurannya dibanding etnik grup lainnya.

${ }^{3}$ Ruffin, David, What The Next Election Meens For You (Black Enterprises 34, June 11th, 2004), 264-270. 
Tingkat pengganguran kulit hitam dua kali lebih tinggi dari kulit putih. Walau para pelamar kerja kulit hitam mempunyai pendidikan tinggi tampaknya lebih mengalami kesulitan mencari pekerjaan dibandingkan kaum kulit putih yang nota-bene pendidikannya lebih rendah. Di Amerika pun masih ada diskriminasi 3 Dua laki-laki Afrika-Amerika di Kota New York berumur antara 18 sampai 54 tahun merupakan pengangguran ${ }^{4}$. Situasi di atas merupakan metafora yang terus ada yang dihadapi Amerika.

Bagaimana kaum etnik Afrika-Amerika tersebut menyelesaikan permasalahan mereka? Bersamaan dengan akan diadakannya pemilihan presiden (pilpres) Amerika pada tahun 2004, maka pilpres tahun 2004 tersebut digunakan sebagai momentum oleh kaum Afrika-Amerika untuk mengambil kesempatan mencari kandidat yang mampu melepaskan mereka dari kesulitan ekonomi mereka atau melepaskan kaum keluarga yang berpenghasilan rendah di seluruh Amerika. Mau tidak mau hal ini menyebabkan kaum Afrika-Amerika mencari strategi dengan berpartisipasi menjadi pemilih kulit hitam yang aktif.

Para analisis ekonomi Amerika setuju bahwa ada masalah yang muncul berkenanan dengan sosial ekonomi Amerika yaitu tidak saja tingginya pengangguran pada etnik Afrika-Amerika, namun juga adanya diskriminasi ras yang ternyata juga memegang peranan penting sebagai penyebab tingginya tingkat pengganguran kaum hitam d Amerika. Maka muncul argumentasi di antara para pengamat ekonomi bahwa pemilihan presiden bukanlah semata-mata hanya memilih seseorang untuk menjadi presiden, namun adalah juga mencari kandidat, baik laki-laki maupun perempuan, yang dipilih pemilih apakah mempunyai perspektif program yang sama dengan yang dibutuhkan oleh pemilih 5 . Oleh karena itu, para pengamat tersebut menyatakan perlu bagi pemilih kulit hitam Amerika menyampaikan kepada kandidat untuk mengadopsi isu sosial ekonomi mereka dan juga memberi posisi jabatan kepada kulit hitam yang berkualitas jika kandidat tersebut ingin didukung oleh kaum kulit hitam.

Pelajaran yang dapat diambil dari pilpres Amerika 2004 ini adalah pemilu juga merupakan suatu sarana atau kesempatan untuk mengangkat isu-isu sosial, ekonomi, budaya, lingkungan yang ada di masyarakat menuju

\footnotetext{
4 Ibid, 265.

5 Ibid, 266.
} 
ke arah yang lebih baik dalam membangun kehidupan masyarakat yang adil dan makmur.

\section{Pilpres Taiwan 2004}

Pada sisi pemilih, dalam tulisan ini, pemilih Taiwan setidaknya dapat dibagi dalam 2 kategori yaitu pemilih yang sudah 'melek (familiar) politik' (punya pengetahun politik, mengetahui isu-isu negara yang relevan, hadir di TPS) dan pemilih yang 'belum melek politik'. Kategori pemilih ini mempengaruhi sukses atau tidaknya pelaksanaan pemilu atau mempengaruhi mau hadirnya pemilih di TPS. Hasil penelitian pemilihan presiden Taiwan 2004 menunjukkan bahwa hal melek politik, bentuk atau isi ulasan kampanye terhadap isu-isu relevan, dan intensitas kampanye dari seorang kandidat atau partai politik peserta pemilu sangat berpengaruh pada hadirnya pemilih di TPS untuk memilih kandidat tersebut ${ }^{6}$.

Hasil studi menunjukkan bahwa isi ulasan kampanye dan intensitas kampanye di media berpengaruh positif terhadap persepsi pemilu Taiwan pada 2004 tersebut. Hal yang menarik adalah bahwa intensitas kampanye yang rendah sekalipun ternyata mampu mendorong para pemilih yang 'yang belum melek politik' ke arah mulai sadar politik walaupun belum sepenuhnya menjadi pemilih yang 'sudah melek politik'. Bagi pemilih yang 'belum melek politik,' informasi pemilu tergantung pada ulasan-ulasan terbaru dari isi kampanye yang didapat dari media. Kelompok pemilih ini akan memberikan perhatian terhadap media tersebut untuk mendapatkan informasi yang baru. Dalam proses ini, pemilih yang 'belum melek politik' akan menjadi lebih rentan (setuju) kepada isi ulasan kampanye media tersebut'. Sebaliknya bagi pemilik yang 'sudah melek politik' intensistas kampanye di media memberikan efek yang sedikit. Penyebabnya adalah

${ }^{6}$ Han Gang, Chock, T. Makana dan Pamela J, Issue Familiarity and Framing Effects of Online Campaign Coverage: Event Perception, Issue Attitudes, and The 2004 Presidential Election Taiwan (Journalism and Mass Communication Quarterly 86.4 (Winter 2009): 739-755.

${ }^{7}$ David Tewksbury, Jennifer Jones, Matthew W. Peske, Ashlea Raymond, and William Vig, The Interaction of News and Advocate Frames: Manipulating audience Perceptions of a Local Public Policy Issue, (Journalism \& Mass Communication Quarterly 77 (winter 2000), 820. 
menurut Price dan Tewksbury' ${ }^{8}$ karena para pemilih yang 'sudah melek politik" sudah terlebih dahulu mempunyai informasi yang lebih mendalam akan pemilu itu sendiri dari berbagai sumber informasi yang lebih luas.

Hasil studi juga menunjukkan bahwa seringkali isi ulasan kampanye media maupun kampanye secara langsung memberikan dampak positif terhadap pemilih 'yang belum melek politik' yaitu membuka kesadaran akan isu politik apa yang sedang terjadi, dan bila kelompok pemilih ini setuju dengan isu yang dikampanyekan maka menjadi keuntungan bagi kandidat yang menyampaikannya 9. Jika intensitas kampanye ini tinggi, maka kelompok pemilih ini akan hadir di TPS.

Pelajaran yang dapat diambil dari pemilihan presiden Taiwan tahun 2014 di atas adalah memberikan informasi hubungan antara peran kampanye, baik melalui media maupun secara langsung terhadap pemilih, khususnya pemilih 'yang belum melek politik'. Kampanye bermanfaat positif bagi pemilih yang 'belum melek politik' namun kurang kritis, karena hanya mendapat informasi dalam jangka waktu yang pendek (selama kampanye saja). Kampanye tersebut mampu mendorong mereka ini datang ke TPS. Kampanye tidak berdampak signifikan bagi pemilih yang 'sudah melek politik, namun pasti mereka ini akan datang ke TPS. Dalam lingkungan dunia yang global sekarang, berbagai berita internasional termasuk informasi pemilu, menjadi lebih mudah diakses melalui berita di internet atau berbagai jejaring sosial.

\section{Pilpres Indonesia, 2014}

Setelah runtuhnya Orde Baru pada tahun 1998, Indonesia telah melaksanakan empat kali pemilu yaitu pada tahun 1999, 2004, 2009 dan 2014 yang sedang berlangsung. Pemilu 199910 dilangsungkan di bawah pemerintahan Presiden BJ Habibie dan diikuti oleh 48 partai politik. Lima besar partai pemenang dalam pemilu 1999 tersebut adalah Partai Demokrasi Indonesia Perjuangan, Partai Golkar, Partai Persatuan

8 Vincent Price dan David Tewksbury, News V alues and Public Opinion: $A$ Theoretical Account of Media Priming and Framing, dalam Progress in the Communication Sciences, ed. George A. Barnett and Franklin J. Foster (Stamford, CT: Ablex, 1997), 173-212.

${ }^{9}$ Ibid 6, 747.

${ }^{10}$ KPU Indonesia 1999. 
Pembangunan, Partai Kebangkitan Bangsa dan Partai Amanat Nasional. Walaupun Partai Demokrasi Indonesia Perjuangan meraih suara terbanyak (dengan perolehan suara sekitar 35 persen), namun yang diangkat menjadi presiden bukanlah calon dari partai tersebut, yaitu Megawati Soekarnoputri, melainkan dari Partai Kebangkitan Bangsa, Abdurrahman Wahid (pada saat itu, Megawati hanya menjadi calon presiden). Hal ini dimungkinkan untuk terjadi karena Pemilu 1999 saat itu hanya bertujuan untuk memilih anggota MPR, DPR, dan DPRD, sementara pemilihan presiden dan wakilnya dilakukan oleh anggota MPR. Tingkat partisipasi pemilih pada tahun 1999 adalah 93 persen.

Pemilu 2004 menjadi catatan sangat penting dalam sejarah pemilu di Indonesia. Pada tahun tersebut untuk pertama kali rakyat Indonesia memilih langsung wakilnya di parlemen dan pasangan presiden serta wakil presiden. Sebelumnya, presiden dan wakil presiden dipilih oleh Majelis Permusyawaratan Rakyat. Oleh karena itu, pelaksanaan pemilu dibagi menjadi dua yaitu pemilu legislatif dan pemilu presiden ${ }^{11}$. Pemilu legislatif digelar sebagai rangkaian pertama pada 5 April 2004 dan diikuti 24 partai politik. Partai-partai politik yang memperoleh suara lebih besar atau sama dengan tiga persen dapat mencalonkan pasangan calonnya untuk maju pada pemilihan Presiden. Hasil lima besar pemilu legislatif 2004 yaitu 1) Golkar $(21,58 \%), 2)$ PDIP (18,53\%). PKB (10,57), PPP (8,12\%), dan PD $(7,45 \%)$. Pemilu presiden tahun 2004 terjadi dalam dua putaran. Hasil pemilu presiden putaran pertama yaitu : 1. Susilo Bambang Yudhoyono - Jusuf Kalla (33,58\%), 2. Megawati Soekarnoputri - Hasyim Muzadi (26.24 \%), 3. Wiranto - Solahuddin Wahid $(22.19 \%)$, 4. Amien Rais - Siswono Yudo Husodo (14.94 \%), dan 5. Hamzah Haz - Agum Gumelar (3.05 \%). Hasil pemilu putaran kedua yaitu . Susilo Bambang Yudhoyono - Jusuf Kalla (60,62 ) dan Megawati Soekarnoputri - Hasyim Muzadi (39,38\%). Dengan demikian, Susilo Bambang Yuhoyono - Yusuf Kalla menjadi presiden pemenang pemilu tahun 2004. Tingkat partisipasi pemilih pada pemilu 2004 adalah $84 \%$.

${ }^{11}$ KPU Indonesia 2004. 
Pada pemilu 200912 ada 9 partai yang lolos dalam pemilihan legislatif yaitu Demokrat (20,85\%), Golkar (14,45\%), PDIP (14,03\%), PKS (7,88\%), PAN (6,01\%), PPP (5,32\%), PKB (4,94), Hanura (3,37\%). Pada pemilihan presiden hanya ada satu putaran dengan hasil : 1) Susilo Bambang Yudhoyono-Budiono (60,80\%), Megawati-Prabowo (26,79\%), dan Yusuf Kalla-Wiranto (12,41\%). Tingkat partsipasi pemilih pada pemilu 2009 turun dibandingkan pemilu sebelumnya menjadi $71 \%$. Penurunan tingkat partisipasi bukanlah hal yang aneh bagi sebuah demokrasi yang baru berdiri. Namun demikian, Mark Singletary ${ }^{13}$ menyatakan bahwa persentasi atau jumlah kehadiran pemilih di TPS berkorelasi positif dengan kualitas pemilu. Semakin tinggi tingkat kehadiran pemilih di TPS, maka kualitas penyelenggaran pemilu tersebut semakin baik. Perolehan data suara Golput sejak era Orde Baru yaitu sejak 1971 dari tahun ke tahun meningkat terus. Bahkan pada pemili 2009 dikatakan yang menang adalah Golungan Putih. Berikut daftar perolehan golput sejak tahun 1971 (masa Orde Baru):

\begin{tabular}{|c|c|}
\hline Tahun & \% Golput \\
\hline 1971 & 6.64 \\
\hline 1977 & 8,40 \\
\hline 1982 & 8,53 \\
\hline 1987 & 8,39 \\
\hline 1992 & 9,09 \\
\hline 1997 & 9,42 \\
\hline 1999 & 10,31 \\
\hline 2004 & 23,34 \\
\hline 2009 & 39,1 \\
\hline
\end{tabular}

12 KPU Indonesia 2009.

13 Singletary, Mark., Commentary: Voter turnout dictates 'most important' election. New Orleans CityBusiness (Nov 3, 2008). 
Dari data daftar suara golput, maka sejak era reformasi, jumlah masyarakat yang abstain atau golput meningkat pesat yakni $10.21 \%$ pada tahun 1999 menjadi 39.1\% di tahun 2009. Angka golput 39.1\% jauh melebihi angka partai Demokrat yang menduduki posisi pertama dalam survei yakni 20\% suara dari (100\%-39\% golput). Tampaknya "Partai Golput" menang mutlak. Perlu dicatat, bahwa angka golput bukanlah semata-mata karena apatisme masyarakat, namun pada tahun 2009 ini angka golput tidak hanya saja masyarakat yang apatis, namun KPU dan Pemerintah secara tidak langsung membungkam hak suara rakyat untuk memilih.

Setidaknya ada 3 faktor utama meningkatnya Golput 2009 yakni:

a) Faktor teknis yang berhubungan dengan Daftar Pemilih Tetap (DPT). Mekanisme pemungutan suara banyak terkendala oleh birokrasi,

b) Sikap apatis terutama pada golongan masyarakat miskin atau perantauan. Penyebabnya adalah mereka merasa siapapun yang menang tidak membawa perubahan kepada kehidupan mereka dan bahkan kehidupan mereka bertambah miskin atau dimiskinkan. Sehingga, golongan masyarakat ini lebih memilih bekerja daripada libur untuk datang ke TPS. Dan angka masyarakat apatis semakin tinggi, dikarenakan banyaknya politisi partai yang mementingkan kepentingan partainya daripada kepentingan masyarakat. Ketika menjelang Pemilu, para petinggi partai gencar menghabiskan puluhan bahkan ratusan miliar untuk iklan janji dan janji. Namun ketika berkuasa, mereka asyik menggeruk kebijakan yang menghasilkan keuntungan partai.

c) Konsep ideologis: Peningkatan angka golput dari masyarakat golongan ideologis ini tidak sepesat masyarakat apatis. Umumnya masyarakat golongan ideologis golput berasal dari kalangan cendekiawan. Mereka memutuskan untuk golput, karena memburuknya sistem politik, apalagi dengan seringnya membawa isu agama. Kebobrokan dan skandal partai yang sering disiarkan media TV semakin menguatkan keyakinan golongan masyarakat ideologis bahwa sudah banyak partai yang tidak benar. Oleh karena itu, golongan ini merasa tidak percaya kepada pemilu. 
Laporan pencapaian pemerintahan SBY dalam 10 tahun menunjukkan adanya sejumlah perubahan ke arah yang lebih baik ${ }^{14}$. Isu yang menjadi program kerja Presiden SBY mencakup 4 bidang yaitu a) Bidang Politik, Hukumm dan Keamanan, b) Bidang Ekonomi dan pembangunan, c) Bidang Pangan, dan c) Bidang Energi. Khusus dalam bidang pemberantasan korupsi di mana Indonesia merupakan salah satu negara yang angka korupsinya tinggi, Presiden SBY melakukan akselerasi pemberantasan korupsi melalui penguatan KPK (Komisi Pemberantasan Korupsi) dan pembentukan beberapa lembaga untuk memberantas korupsi serta tidak pernah membela koruptor ${ }^{15}$. Dalam bidang ekonomi, pertumbuhan ekonomi Indonesia sepanjang periode 2004-2012 merupakan pertumbuhan yang paling stabil yaitu 4,63 - 6.5\% dibanding periodeperiode sebelumnya ${ }^{16}$. Dalam bidang pangan, anggaran sektor pertanian meningkat sebanyak 16,2\% dalam kurun waktu 2004-2013. Hal ini merupakan cerminan dalam upaya meningkatkan produksi pangan. Maka, harapan dari hasil pemilihan presiden 2014 adalah pemimpin yang baru tetap mempertahankan atau meneruskan perubahan yang telah dilakukan oleh pemimpin sebelumnya bahkan presiden baru yang terpilih dapat memberikan perubahan yang lebih baik dibanding perubahan sebelumnya.

Pelajaran yang dapat diambil dari pilpres Indonesia 2014 adalah penurunan yang signifikan dari pemilih atau golput yang tinggi di Indonesia harus menjadi perhatian pemerintah. Suksesnya suatu pemilu dilihat melalui kehadiran di pemilih datang ketempat TPS.

\section{Perspektif Alkitab}

Alkitab menunjukkan bahwa tatanan kehidupan masyarakat di zaman Alkitab tidak pernah lepas dari masalah kepemimpinan. Seperti disebutkan sebelumnya dalam bagian pendahuluan bahwa Allah menyampaikan rencana dan misinya bagi dunia melalui sejarah kehidupan manusia. Alkitab dengan tegas dan jelas menunjukkan bagaimana Allah sendiri mendukung atau menolong umat-Nya untuk memilih pemimpin bagi mereka yang sesuai dengan karakter Allah. Para nabi seperti Musa, Yesaya dan Yehezkiel, para hakim seperti otniel, Debora dan Gideon, para raja sepeti 2013; hal.47.

${ }^{14}$ Capaian Pemerintah SBY KIB 1 dan KIB 2. Terbitan Sekretariat Negara,

${ }^{15}$ Ibid 14, 4.

${ }^{16}$ Ibid 15, 10. 
Saul dan Daud, para rasul seperti Petrus dan Paulus dan juga sampai para Penatua dan Diaken dalam Titus 1 merupakan contoh para pemimpin yang mewakili sejarah kehidupan umat Allah di zamannya masing-masing. Maknanya adalah kepemimpinan merupakan hal yang penting dalam perspektif Allah.

Pemimpin dalam kamus Bahasa Indonesia berarti orang yang memimpin, orang yang memberi petunjuk, orang yang memberi pedoman atau arahan, orang yang dapat memberikan perlindungan dan keamanan. Yang termasuk pemimpin misalnya: atasan, bos, kepala, ketua, komandan, koordinator, majikan, master, direksi, imam, panglima, pemuka, presiden, pelopor, penganjur, perintis, suami sebagai kepala keluarga, orangtua sebagai pemimpin anak-anak, dan sebagainya. Pemimpin harus memberikan keteladan yang baik dalam setiap aspek kehidupannya. Pemimpin juga dituntut untuk mempunyai integritas dalam kehidupannya.

Alkitab memberikan petunjuk untuk hidup yang berintegritas. Dalam Titus 1: 6-14 ditunjukkan syarat-syarat yang harus dimiliki oleh seorang pemimpin adalah a) tidak bercacat dalam kesaksian hidup, b) jika menikah harus monogamy c) jika mempunyai anak, anaknya harus hidup beriman dan kudus, d) tidak angkuh, e) bukan pemarah, f) bukan peminum, g) tidak serakah, h) suka memberi tumpangan, i) suka akan yang baik, bijaksana dan adil, j) saleh, k) dapat menguasai diri, l) melakukan firman, m) menasihati orang berdasarkan firman, dan n) sanggup meyakinkan lawannya. Dalam Timotius 4: 6-16 pemimpin harus a) menjauhi takhayul, b) rajin beribadah, c) memegang janji, d) bertekun membaca kitab suci, e) menjaga diri dan mengawasi ajaran firman Allah.

Jim Wallis ${ }^{17} 18$ menyatakan bahwa politik dan agama tidak boleh dipisahkan, justru merupakan kesatuan. Agama merupakan unsur faktor moral yang paling penting dalam pemilihan umum khususnya dalam kampanye untuk menarik simpati pemilih. Sebagai contoh, banyak para politisi Amerika salah menggunakan konteks agama dalam kampanyenya. Mereka menyatakan bahwa Tuhan ada disisi/partai mereka sehingga

${ }^{17}$ Jim Wallis, God's Politics - Why the American Right Gets it Wrong and the Left Left Doesn't Get it. (Griffin Press, 2005, Australia), xix-xxx. 
pemilih harus memilih mereka (partainya juga). Wallis menegaskan bahwa Allah bukan milik partai. Banyak para kandidat tidak menyadari bahwa isuisu sosial yang mereka kampanyekan sebenarnya adalah merupakan isu-isu agama. Contoh misalnya: a) Isu kemiskinan juga merupakan isu agama yaitu tentang menolong sesama (Matius 25: 35-40, Yesaya 10:1-2), b) isu kerusakan lingkungan, bukankah ini isu agama juga, yaitu memelihara dan mengelola bumi (Kejadian 2:15, Maz 24:1), c) Kampanye isu perang, ini juga isu agama, bukankah kita diminta menjadi pembawa damai (Matius 5:9), d) isu kebenaran, juga merupakan isu agama (Yoh 8:32), e) kampanye hak asasi manusia, juga isu agama karena merefleksikan gambar Allah dalam ciptaan manusia (Kej 1: 27), dan banyak lagi isu-isu lain yang dikampanyekan kandidat dan ternyata semuanya isu agama. Alkitab dapat menjawab seluruh isu sosial yang berhubungan dengan manusia. Oleh karena itu, setiap kandidat seharusnya memberlakukan seluruh nilai-nilai agama dalam kehidupan berpolitiknya. Seluruh aspek aktivitas yang dikerjakan dalam berpolitik adalah perspektikf Alkitab itu sendiri.

\section{Penutup}

Pada pemilihan presiden 2004 di Amerika ditunjukkan bahwa pemilihan umum ternyata dapat dipakai sebagai sarana oleh pemilih menyampaikan aspirasi isu sosial, ekonomi, budaya, dan lingkungan yang ada di masyarakat. Pemilih dan kandidat dapat melakukan tawar menawar. Pemilih pasti akan datang ke TPS dan memilih kandidat tersebut jika platform kampanye kandidat sesuai dengan isu yang mereka sampaikan. Namun sering juga kedatangan pemilih ke TPS, khususnya pemilih yang "belum melek politik" bukan karena kesamaan platform pemilih dan kandidat, tapi kerena kasus suap (money politics). Pemilu Indonesia juga tidak terlepas dari persoalan kasus suap .

Pada pemilihan presiden Taiwan 2004 menunjukkan bahwa seringkali juga isi ulasan kampanye media maupun kampanye secara langsung memberikan dampak positif terhadap pemilih 'yang belum melek politik'. Kampanye dapat membuka kesadaran pemilih yang 'belum melek politik" akan isu politik apa yang sedang terjadi, dan bila kelompok pemilih ini setuju dengan isu yang dikampanyekan maka menjadi keuntungan bagi kandidat yang menyampaikannya. Jika intensitas kampanye tinggi maka kelompok pemilih yang 'belum melek politik' ini hadir di TPS. Kampanye bermanfaat positif bagi pemilih yang 'belum melek politik,' namun kurang kritis karena hanya mendapat informasi dalam jangka waktu yang pendek 
(selama kampanye saja). Kampanye tidak berdampak signifikan bagi pemilih yang 'sudah melek politik, namun pasti mereka akan datang ke TPS. Dalam lingkungan dunia yang global sekarang, pemilih yang 'sudah melek politik' aktif mencari berbagai informasi poitik melalui berita nasional maupun internasional karena informasi tersebut diakses melalui berita di internet atau berbagai jejaring sosial.

Pemilihan Presiden merupakan salah satu instrumen yang penting bagi suatu negara untuk memilih pemimpinnya. Pemilihan presiden yang berkualitas adalah jika tingkat partisipasi pemilih ke TPS tinggi. Penyelenggaraan pemilu Indonesia sejak tahun 1999 sampai tahun 2009 memperlihatkan semakin tingginya orang yang tidak datang ke TPS atau disebut juga golput. Pada penyelengaraan pemilu 2009 hasilnya dikatakan merupakan kemenangan golput karena persentase golput mencapai angka lebih dari 30\% lebih sedangkan partai pemenang saat itu hanya mencapai angka 20\%. Kasus suap merupakan masalah terbesar yang dihadapi pemilu di Indonesia. Pemilih datang ke TPS adalah karena diberi uang oleh kandidat tertentu. Ini juga salah satu penyebab orang menjadi pemiih golput. Tingginya angka golput ini harus menjadi perhatian bagi pemerintah Indonesia. Persentasi tingkat kehadiran pemili di TPS menggambarkan kredibilitas pemilu. Segala permasalahan atau berbagai kendala yang muncul dalam penyelenggaraan pemilu harus dijadikan evaluasi dan pembelajaran agar tidak terulang lagi pada pada penyelenggaraan pemilu berikutnya.

Alkitab menunjukkan bahwa politik dan agama merupakan kesatuan yang tidak dapat dipisahkan. Agama merupakan unsur moral dalam politik. Para kandidat yang terlbat dalam politik harus memberlakukan seluruh nilai-nilai agama dalam kehidupan berpolitiknya. Seluruh aspek aktivitas yang dikerjakan dalam berpolitik adalah perspektikf Alkitab itu sendiri. Oleh karena itu orang Kristen turut bertanggungjawab menyukseskan penyelenggaraan pemilu di tempatnya masing-masing.

RATNA KATHARINA menyelesaikan pendidikan S1 (drh), S2 (M.Si.) dan S3 dari Institut Pertanian Bogor. Saat ini menjadi dosen tetap di STT SAPPI. 